\title{
STRUKTUR SEMANTIS VERBA SENTUH BAHASA INDONESIA
}

\author{
Fikry Prastya Syahputra \\ Universitas Sumatera Utara, Medan, Indonesia \\ Email: fikryprastya@yahoo.com \\ T. Silvana Sinar \\ Universitas Sumatera Utara, Medan, Indonesia \\ Email: tinasinar@gmail.com
}

\begin{abstract}
This study focused on the semantic field for the categorization of meaning, kind of meaning and semantic structure of verbs touch in Indonesian (verba sentuh). The reason of this research is the discovery of ambiguous meaning of a word when we refer to the monolingual dictionary that exists today. The method used is descriptive method with a form of qualitative research. The data in this study is verbs touch and source of research was obtained from the dictionary of Indonesian language (Kamus Besar Bahasa Indonesia) in 2008. The theory used in this analysis is the theory of Natural Semantic Metalanguage (NSM). Data were analyzed using three stages, data reduction, data presentation and conclusion/verification. The analysis result obtained was four original meaning which holds a stake in touch verb formation, namely: [FEEL], [BEAT], [PRESSING] and [RUB]. The other components that make up the touch verb is 'someone' and 'something'. This study is only a fraction of the research from Natural Semantic Metalanguage data sourced from Indonesian. This research is expected to contribute for other Natural Semantic Metalanguage research. So that later can be arranged a monolingual Bahasa dictionary based on Natural Semantics Metalanguage.
\end{abstract}

Keywords: Verba Touch, NSM, semantic structure

\begin{abstract}
ABSTRAK
Penelitian ini difokuskan pada bidang semantik untuk kategorisasi makna, jenis makna dan struktur semantik dari verba sentuh dalam bahasa Indonesia. Alasan yang menjadi latar belakang penelitian ini adalah ditemukannya keambiguan makna suatu kata apabila kita merujuk pada kamus monolingual yang ada saat ini. Metode yang digunakan adalah metode deskriptif dengan bentuk penelitian kualitatif. Data pada penelitian ini berupa verba sentuh dan sumber data penelitian diperoleh dari kamus (KBBI) pada tahun 2008. Teori yang digunakan dalam analisis ini adalah teori Metabahasa Semantik Alami (MSA). Teknik analisis data menggunakan tiga tahap yaitu, reduksi data, penyajian data dan penarikan kesimpulan/verifikasi. Hasil analisis yang didapat adalah empat makna asali yang memegang andil dalam pembentukan verba sentuh, yaitu: [MERASAKAN], [MEMUKUL], [MENEKAN] dan [MENGGOSOK]. Komponen lain yang membentuk verba sentuh adalah 'seseorang' dan 'sesuatu'. Penelitian ini hanya sebagian kecil dari penelitianpenelitian Metabahasa Semantik Alami yang bersumber data dari bahasa Indonesia. Diharapkan dengan adanya penelitian ini akan dapat berkontribusi pada penelitian Metabahasa Semantik Alami yang lain. Agar nantinya dapat disusun sebuah kamus monolingual bahasa Indonesia berdasarkan Metabahasa Semantik Alami.
\end{abstract}

Kata kunci: Verba Sentuh, MSA, Struktur Semantis 


\section{PENDAHULUAN}

Bahasa Indonesia memiliki tiga tipe verba. Verba tersebut, yakni (a) verba keadaan; (b) verba proses dan (c) verba tindakan. Artikel ini membahas salah satu tipe verba tindakan bahasa Indonesia, yaitu verba 'sentuh'. Pemilihan verba sebagai objek kajian pada penelitian ini karena kehadiran verba sangat berpengaruh terhadap pembuatan sebuah kalimat. Jumlah leksikon verba 'sentuh' bahasa Indonesia cukup banyak, dan memiliki unsurunsur makna khas yang terkandung di dalamnya sebagai pembeda. Selain itu, verba 'sentuh' mengandung banyak bentuk verba yang berbeda yang dipengaruhi oleh instrumen 'sentuh' ataupun alat yang digunakan. Hal tersebut perlu dikaji secara lebih mendalam, untuk memperoleh gambaran yang jelas prihal pengkategorisasian verba 'sentuh' dalam bahasa Indonesia serta apaapa saja yang tergolong sebagai verba 'sentuh'.

Mengambil contoh dalam kasus penerjemahan, ada kalimat dari bahasa Inggris yang berbunyi 'I love you' diterjemahkan menjadi 'aku cinta kamu' secara umum. Namun ada kalanya penerjemahan bisa berubah menjadi; 'saya cinta kamu' atau 'aku mencintaimu' bisa juga 'aku sayang kamu' dan 'diriku menyukaimu'. Pada tataran dasar tentu bukan masalah besar berbedaan seperti itu dan kita cenderung memilih kalimat terjemahan pertama sebagai suatu terjemahan yang pas. Namun bila dikaji pada tingkat lanjutan (linguistik) tentu tidak akan seperti ini.

Dalam linguistik ini terdapat suatu sub disiplin yaitu semantik yang khusus mempelajari makna bahasa. Pada kasus sebelumnya penggunaan 'aku' atau 'saya' akan lebih jelas perbedaannya bila dilihat dari kacamata semantik. Kamus tidak memberikan penjelasan rinci akan hal tersebut. Kamus hanya menyediakan pilihan kata apa saja yang cocok untuk terjemahan tersebut. Terlebih lagi, kamus sering memasukkan kata yang sama atau mirip untuk diambil/dijadikan arti untuk kata yang lain. Masih menggunakan kasus diatas, ketika seseorang ingin mencari tahu perbedaan kata 'cinta' dan 'suka' maka pada kamus bahasa 
monolingual akan muncul kedua kata kata:

tersebut pada akses masing-masing

\section{KBBI Offline 1.5.1}

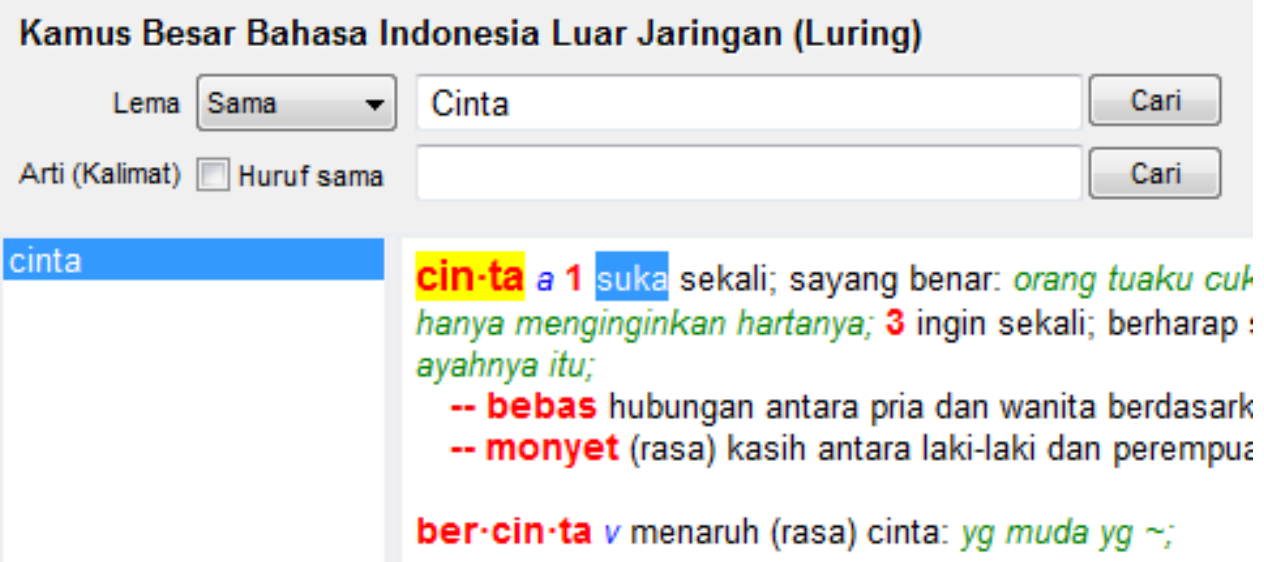

(Gambar 1.1 arti kata 'cinta')

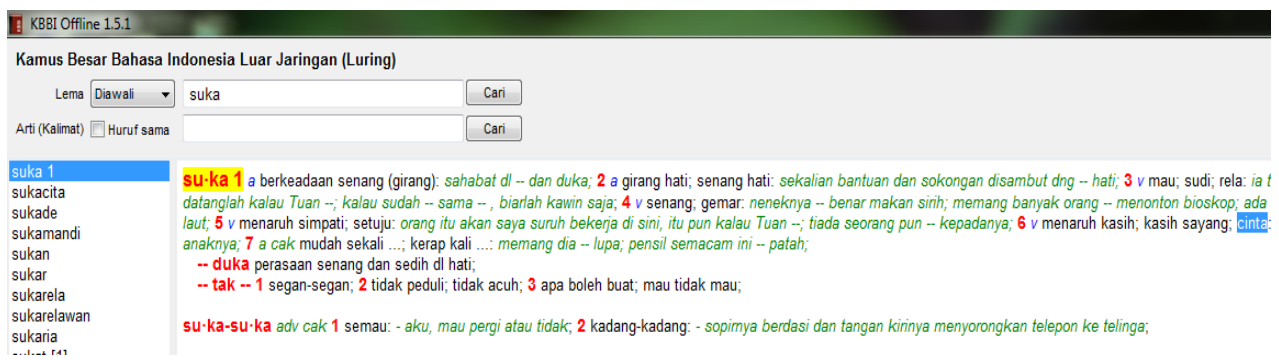

(Gambar 1.2 arti kata suka)

Kita bisa melihat

Artikel penelitian ini mencoba

keberputaran dalam memaknai suatu kata yang disajikan oleh kamus monolingual. Peirce dalam Saeed (2003) menggunakan istilah 'Circulatory' untuk menamai peristiwa berputar-putarnya makna seperti diatas. Menyikapi hal tersebut Saeed (2003) kemudian mengemukakan suatu pendapat bahwa untuk memecahkan masalah berputarnya makna seperti kasus diatas peneliti disarankan untuk menggunakan teori metabahasa. untuk memecahkan masalah berputarnya makna bahasa yang disebabkan oleh sajian makna oleh kamus. Beranjak dari pendapat Saeed (2003) penulis menggunakan teori metabahasa namun lebih difokuskan lagi pada Metabahasa Semantik Alamiah (MSA). Teori MSA yang digunakan adalah menurut Wierzbicka (1996) dan data yang akan diteliti adalah verba sentuh. Verba sentuh dipilih karena belum ada yang menelitinya. 
TEORI DAN METODOLOGI

Teori

Pembahasan utama dalam penelitian ini adalah tataran kata dalam kelas verba. Verba adalah kata yang mengacu pada peristiwa (Mulyadi: 2000). Verba yang berlangsung cepat seperti 'menampar' dan 'menembak'. Verba yang berlangsung lama seperti 'menulis' dan 'belajar'.

Verba yang dibahas pada artikel penelitian ini adalah verba sentuh yang memiliki turunan verba seperti; meraba dan membelai. Penentuan makna dari turunan verba sentuh dilakukan dengan menganalisis komponen-komponen semantis yang berfungsi sebagai pembeda dan perumusan makna. Komponen seperti 'seseorang', 'sesuatu' dan 'merasakan' menyusun makna dari tiap-tiap turunan verba yang nantinya akan membedakan antara makna satu dengan lain.

Teori yang digunakan dalam artikel penelitian ini adalah teori Metabahasa Semantik Alami (MSA). Teori Metabahasa Semantik Alami (MSA) merupakan kajian semantik leksikal. Teori MSA dipilih karena dapat menetapkan kategorisasi dan mengeksplikasi semua makna leksikal, gramatikal, ilokusi dan pragmatik, termasuk aspek tata bahasa dan tipologi universal melalui seperangkat elemen sederhana. Parafrase makna yang dihasilkan mudah dipahami oleh banyak orang, khususnya penutur jati bahasa yang dibicarakan sebab parafrasenya dibingkai dalam sebuah metabahasa yang bersumber dari bahasa alamiah (Mulyadi, 2012).

$\begin{array}{ccr}\text { Teori } & \text { MSA } & \text { yang } \\ \text { dikembangkan } & \text { dalam } & \text { artikel }\end{array}$
penelitian ini adalah konsep makna asali dan polisemi dari suatu kata. Makna asali dimunculkan untuk menjawab permasalah berputarputarnya makna ketika hendak memaknai suatu kata sementara polisemi digunakan untuk menjabarkan dua perangkat makna asali dalam suatu verba tersebut.

Dalam tabel kumpulan makna asali oleh Wierzbicka(1996) yang sudah dimodifikasi oleh Mulyadi. Verba sentuh (touch) merupakan makna asali yang berkomponen pada tindakan, peristiwa, gerakan serta perkenaan. Sudah jelas bahwa verba sentuh adalah peristiwa, dan ia berupa gerakan. Gerakan tersebut 
adalah tindakan dan dalam gerakan tersebut ada sesuatu yang berkenaan satu sama lain. Peneliti mengambil sebuah contoh hasil analisa yang menggunakan makna asali dan polisemi untuk menentukan makna. Pada verba pengelihatan terdapat turunan verba menonton yang dibentuk oleh dua makna asali yaitu [MELIHAT] dan [MEMIKIRKAN]

X melihat Y selama beberapa saat

Karena X memikirkan sesuatu seperti ini:

Sesuatu dapat terjadi pada Y sekarang

Aku ingin mengetahui ini $\mathrm{X}$ melihat Y seperti ini (Mulyadi: 2000)

\section{Metode penelitian}

Penelitian ini menggunakan metode kualitatif yang diperkenalkan oleh Miles, Huberman dan dimodifikasi oleh Saldana (2014). Menurut mereka penelitian dengan metode ini menggunakan empat tahap. Ke empat tahap tersebut saling berkesinambungan dan suatu waktu dapat mengalami proses pengulangan.

Metode ini digunakan karena sesuai dengan objek penelitian. Data yang dianalisis adalah kata. Pada penelitian ini tidak menggunakan penghitungan dan angka. Alur pengumpulan data, penyajian data, analisis data hingga penarikan kesimpulan awal sesuai dengan prosedur alur penelitian yang dikemukakan oleh Miles, Huberman dan Saldana (2014). Mengambil pendapat dari Miles, Huberman dan Saldana (2014), penelitian kualitatif adalah jenis penelitian yang berpusat pada tujuan dari peneltian dan dikaji dengan teori - teori yang sesuai, guna tercapainya tujuan penelitian.

Sumber data adalah verba sentuh dalam bahasa Indonesia. Untuk mencari data digunakan intuisi dari penulis dan juga bantuan Kamus Besar Bahasa Indonesia (KBBI) edisi tahun 2008 dibantu dengan kamus KBBI Luring versi 1.5 .1 sebagai acuan awal dalam mengumpulkan data. Sebab data yang akan diteliti adalah verba-verba turunan verba sentuh seperti membelai, memijat dan lainlain.

Dalam pengumpulan data pada penelitian ini digunakan teknik pengumpulan data berupa teknik pustaka dan catat dari sumbersumber tertulis. Kata yang 
kemungkinan bermakna menyentuh dituliskan sebanyak-banyaknya dari referensi yang ada. Setelah itu dilakukan pengecekan ulang dengan cara menuliskannya di kolom cari kamus KBBI Luring. Apabila ada makna menyentuh dalam arti yang muncul dalam kata tersebut, peneliti menetapkannya sebagai data sementara. Sesuai dengan metode yang digunakan apabila pada kesimpulan yang didapat belum cukup untuk menjawab permasalahan dalam penelitian, akan dilakukan pengumpulan data kembali.

Setelah mendapatkan cukup data, peneliti masuk ketahap selanjutnya, yaitu mengelompokkan data berdasarkan kedekatan makna. Dalam proses ini peneliti mengkatagorikan data berdasarkan apa yang digunakan untuk menyentuh dan apa yang disentuh.

Analisis data dilaksanakan dengan menetapkan komponen semantis sebagai dasar pengelompokkan verba dan perangkat makna asali sebagai alat penetapannya. Kemudian dimunculkan data kalimat sebanyak mungkin (berdasarkan data awal: verba sentuh) untuk melihat kesesuaian kata terhadap makna kalimat serta menguji keberterimaannya. Peneliti membagi proses penganalisaan data menjadi tiga bagian; Kondensasi data, data ditampilkan dan pemaparan kesimpulan serta peninjauan ulang (Miles, Huberman dan Saldana 2014). Ketika melakukan kondensasi data, pada tahap pertama dilakukan pemilihan data. Pemilihan ini dilakukan dengan cara memilih katakata yang dianalisa. Kata-kata yang tidak berterima setelah diuji dalam kalimat dihilangkan. Pada tahap kedua yaitu pemfokusan data, data yang telah dipilih dicek ulang dengan kamus luring KBBI. Pada tahap ketiga dan empat dalam kondensasi data, penyederhanaan data dan analisis data tersebut sesuai teori MSA yang dikemukakan oleh Wierzbicka (1996). Tahap analisisnya adalah: (1) Parafrase, menggunakan kombinasi sejumlah makna asali yang telah diusulkan oleh Wierzbicka. Kombinasi sejumlah makna asali diperlukan terkait dengan klaim dari teori MSA, yaitu suatu bentuk tidak dapat diujarkan hanya dengan memakai satu makna asali. (2) 
Parafrase dapat pula digunakan dengan memakai unsur yang merupakan kekhasan suatu bahasa. Hal ini dapat dilakukan dengan menggabungkan usur-unsur yang merupakan keunikan bahasa itu sendiri untuk menguraikan makna. (3) Kalimat paraphrase harus mengikuti kaidah sintaksis bahasa yang dipakai untuk memparafrase. (4) Parafrase selalu menggunakan bahasa yang sederhana. (5) Kalimat parafrase kadang-kadang memerlukan indentasi dan spasi khusus.

Pada tahap akhir, peneliti memaparkan hasil dari tahap tiga dan empat kedalam pembahasan penelitian ini. Data yang ditampilkan berbentuk uraian. Setiap kata verba turunan verba sentuh akan dibahas satu persatu dengan aspek makna asali dan komponen semantisnya. Serta ditambahi dengan contoh kalimat yang sesuai. Pada tahapan ini pula nantinya yang digunakan sebagai acuan pembentukan kesimpulan awal.

\section{HASIL DAN PEMBAHASAN}

Struktur semantis verba sentuh dalam bahasa Indonesia terbentuk dari elemen [MENYENTUH] dengan elemen [MERASAKAN], [MEMUKUL], [MENEKAN] dan [MENGGOSOK]. Oleh karena itu polisemi yang dihasilkan adalah [MENYENTUH/MERASAKAN], [MENYENTUH/MEMUKUL], [MENYENTUH/MENEKAN] dan [MENYENTUH/MENGGOSOK]. Dasar semantisnya adalah seseorang yang [MENYENTUH] sesuatu/seseorang, ia ingin [MERASAKAN] sesuatu, dan ketika ia [MENYENTUH] sesuatu/seseorang, ia seperti [MEMUKUL] dan [MENEKAN]-nya. Apabila seseorang [MENYENTUH] sesuatu dengan tujuan tertentu akibat sesuatu hal, ia akan [MENGGOSOK]-nya secara sengaja ataupun tidak disengaja. Untuk bahasan lebih lanjut akan ditampilkan analisis berdasarkan uraian polisemi diatas:

\section{Menyentuh/Merasakan}

[MENYENTUH]

[MERASAKAN] menjelaskan makna mengusap, meraba, mengelus, membelai, menjamah, mencium dan menjilat. Adapun perbedaan yang kasat mata terletak pada bagian tubuh yang digunakan untuk menyentuh dan bagian tubuh / 
sesuatau yang disentuh. Mengusap, meraba, mengelus, membelai, menjamah menggunakan telapak tangan bagian dalam dan juga jarijemari. Mencium menggunakan bibir dan menjilat menggunakan lidah. Adapun berbedaan lebih lanjut dari mengusap, meraba, mengelus, membelai, menjamah terletak pada sesuatu yang disentuhnya. Gagasan umum untuk mengkatagorikan verba-verba ini kedalam makna [MENYENTUH] / [MERASAKAN] terletak pada:

a. X menyentuh $\mathrm{Y}$ karena $\mathrm{X}$ merasakan sesuatu

b. Sesuatu yang $\mathrm{X}$ rasakan bisa diakibatkan oleh Y

c. Ataupun $\mathrm{X}$ ingin merasakan $\mathrm{Y}$

\section{Mengusap}

$\mathrm{X}$ menyentuh $\mathrm{Y}$ dengan telapak tangan dan bagian dalam jari-jarinya.

Karena X merasakan sesuatu

Dan Y juga merasakan sesuatu

Yang membuat $\mathrm{X}$ juga merasakan sesuatu

Contoh Kalimat:

$\checkmark \quad$ Ia mengusap lukanya sambil mengingat nasibnya yg sial

$\checkmark \quad$ Ibu mengusap wajah setelah berdoa

$\checkmark$ Suami yang mengusap air mata istri, menghapus kesedihannya maka Allah membukakan pintu surga baginya dan keluarganya.

\section{Meraba}

$\mathrm{X}$ menyentuh Y dengan telapak tangan dan bagian jari-jarinya Karena X ingin merasakan sesuatu Dan Y merasakan sesuatu juga akibat $\mathrm{X}$

Namun adakalanya Y tidak merasakan sesuatu

$\checkmark$ Orang buta itu meraba tongkatnya.

$\checkmark \quad$ Penjaga itu meraba saku orang yg dicurigainya.

$\checkmark$ Budi yang pendatang itu masih meraba jalan di kota barunya.

\section{Mengelus}

$\mathrm{X}$ menyentuh Y dengan telapak tangan dan bagian depan jari-jarinya Karena X merasakan sesuatu pada Y Dan Y mendapatkan sesuatu dari X $\mathrm{X}$ ingin $\mathrm{Y}$ merasakan sesuatu

$\checkmark$ Anak kecil itu mengelus kucingnya dengan penuh rasa sayang.

$\checkmark$ Nenek mengelus cucunya hingga tertidur.

$\checkmark$ Betty mengelus kakinya yang sakit.

\section{Membelai}

$\mathrm{X}$ menyentuh Y dengan telapak tangan dan jari-jari bagian depan $\mathrm{X}$ menyentuh $\mathrm{Y}$ tepat di bagian rambut X mersakan sesuatu pada Y 
Dan ingin Y merasakan sesuatu juga

$\checkmark \quad$ Ingin sekali aku memeluk kepalanya dan membelai rambutnya.

$\checkmark \quad$ Ia membelai kekasihnya dengan mesra.

$\checkmark \quad$ Ibu yang panik itu membelai lembut anaknya yang sedang sakit.

\section{Menjamah}

$\mathrm{X}$ menyentuh Y dengan telapak tangan dan jari-jari bagian depan

$\mathrm{X}$ merasakan sesuatu pada $\mathrm{Y}$

$\mathrm{X}$ ingin melakukan sesuatu pada $\mathrm{Y}$

Y belum tentu merasakan dan

menginginkan hal yang sama

$\checkmark \quad$ Ia menjamah tubuh orang itu.

$\checkmark \quad$ Pemuda itu menjamah buah mangga terendah.

$\checkmark \quad$ Ia menjamah keumpulan permen di depannya.

\section{Mencium}

$\mathrm{X}$ menyentuh $\mathrm{Y}$ dengan ujung bibir

X merasakan sesuatu pada $Y$

Y juga merasakan hal yang sama

Namun adakalanya Y tidak

merasakan apa-apa

$\checkmark \quad$ Ia mencium kekasihnya sebelum pergi ke Suriah

$\checkmark \quad$-Anto mencium pantat kuali sebagai hukuman dari ibunya.

$\checkmark$ Ayah yang baru pulang itu langsung mencium anaknya yang menyambutnya pulang.

\section{Menjilat}

$\mathrm{X}$ menyentuh $\mathrm{Y}$ dengan lidah

$\mathrm{X}$ ingin merasakan sesuatu dari $\mathrm{Y}$

$\checkmark$ Ratna menjilat es krim yang hampir meleleh itu.

$\checkmark$ Rudy selalu menjilat piringnya sehabis makan.

$\checkmark$ Anjing itu menjilat kaki anakyg sedang duduk di kursi.

\section{Menyentuh/Memukul}

[MENYENTUH] / [MEMUKUL] menjelaskan makna menepuk. Bagian tubuh yang digunakan untuk menyentuh adalah telapak tangan bagian dalam dan jari-jemari serta objek yang disentuh bisa berupa bagian tubuh / suatu benda. Gagasan umum untuk mengkatagorikan verba ini kedalam makna [MENYENTUH] / [MEMUKUL] terletak pada:

\section{Menepuk}

$\mathrm{X}$ menyentuh $\mathrm{Y}$ dengan telapak tangan dan jari-jari bagian depan $\mathrm{X}$ seperti memukul Y namun dengan pelan, tidak menimbulkan efek $\mathrm{X}$ memiliki sesuatu yang ingin disampaikan pada Y Bukan berarti X harus berbicara pada Y

\section{$\checkmark$ Menepuk air}

$\checkmark \quad$ Pada waktu berpisah, ia menepuk bahu kawannya sambil berseru riang. 
Pelatih itu menepuk punggung si nomor 10.

\section{Menyentuh Menekan}

\section{[MENYENTUH] / [MENEKAN]} menjelaskan makna mengurut, menyolek, memetik, menggaruk, menggores dan memijak. Adapun perbedaan yang kasat mata terletak pada bagian tubuh yang digunakan untuk menyentuh dan bagian tubuh / sesuatau yang disentuh. Mengurut, menyolek, memetik, menggaruk, menggores menggunakan tangan. Memijak menggunakan kaki. Lebih lanjut mengurut, menyolek, memetik, menggaruk, menggores bisa dibedakan lagi lebih spesifik. Mengurut menggunakan telapak tangan bagian dalam dan jari-jemari. Menyolek dengan jari telunjuk, memetik denga jari-jemari sedangkan menggaruk dan menggores menggunakan telapak tangan bagian dalam dan jari-jemari + bisa menggunakan alat khusus / tertentu. Objek yang disentuh bervariasi. Gagasan umum untuk mengkatagorikan verba-verba ini kedalam makna [MENYENTUH] / [MENEKAN] terletak pada:

a. X menyentuh Y dengan cara menekan

b. X menimbulkan efek pada Y c. Akibatnya Y bisa menghasilkan sesuatu, mengalamai sesuatu

\section{Mengurut}

$\mathrm{X}$ menyentuh Y dengan telapak tangan dan jari-jari bagian depan $\mathrm{X}$ menyentuh sambil menekan $\mathrm{X}$ ingin $\mathrm{Y}$ menjadi lebih baik $\mathrm{X}$ melakukan pekerjaan yang menyembuhkan

$\checkmark$ Orang itu terkenal krn pandai mengurut.

$\checkmark$ Mengurut adalah salah satu keahlian pak Tarno yang tidak bisa melihat.

$\checkmark$ Ali mengurut sendiri kakinya yang cedera.

\section{Menyolek}

$\mathrm{X}$ menyentuh Y dengan jari telunjuk

$\mathrm{X}$ menyentuhnya dengan sedikit

menekan

$\mathrm{X}$ memiliki sesuatu yang hendak disampaikan pada Y

Bukan berarti X ingin berbicara pada Y

$\checkmark$ Gadis itu menyolek pipi bayiyg gemukitu.

$\checkmark \quad$ Ia menyolek sedikit rendang yang baru matang itu.

Susi menyolek temannya mengajak pergi.

\section{Memetik}

$\mathrm{X}$ menyentuh Y dengan jari-jarinya 
$\mathrm{X}$ menyentuh dengan menekan

sedikit

$\mathrm{X}$ tidak mengambil sesuatu dari Y

$\mathrm{X}$ hanya menghasilkan sesuatu pada saat menyentuh Y dengan sedikit menekan

$\checkmark$ Banyak orang butayg pandai memetik kecapi.

$\checkmark \quad$ Jika ada orang memetik jari di dekat sangkar, berbunyilah burung itu.

$\checkmark$ Ubid pandai memetik gitar.

\section{Menggaruk}

$\mathrm{X}$ menyentuh $\mathrm{Y}$ dengan kuku

$\mathrm{X}$ sedikit menekan

$\mathrm{X}$ melakukan gerakan maju mundur

$\mathrm{X}$ merasakan sesuatu sebelum dan sesudah menyentuh $\mathrm{Y}$

$\checkmark$ Aku terkejut, kukira ada apa, rupanya anjing menggaruk di tanah.

$\checkmark \quad$ Ia selalu menggaruk kepalanya

$\checkmark$ Budi menggaruk seluruh tubuhnya yang gatal-gatal.

\section{Menggores}

$\mathrm{X}$ menyentuh $\mathrm{Y}$ dengan alat

$\mathrm{X}$ menekan Y dengan sedikit keras

$\mathrm{X}$ menghasilkan sesuatu dari kegiatan

tersebut

$\checkmark \quad$ Ia tak sengaja menggores $C R-V$ tetangganya.

$\checkmark \quad$ Ia menggores kanvas kosong itu menjadi sebuah karya. $\checkmark \quad$ Ia menggores pipinya dengan pisau cukur.

\section{Memijak}

$\mathrm{X}$ menyentuh Y dengan telapak kaki X menekan Y

$\checkmark \quad$ Ia memijak dahan kering itu hingga patah

$\checkmark \quad$ Ia memijak kotoran sapi

Ia memijak kulit pisang

Menyentuh/Menggosok

[MENYENTUH]

[MENGGOSOK] menjelaskan makna menghapus, menyeka, menggesek dan mengasah. Adapun perbedaan yang kasat mata terletak pada alat yang digunakan untuk menyentuh dan apa yang disentuh. Objek yang disentuh bervariasi. Gagasan umum untuk mengkatagorikan verba-verba ini kedalam makna [MENYENTUH] / [MENGGOSOK] terletak pada:

a. X menyentuh Y dengan alat

b. Gerakan yang dilakukan adalah majumndur.

c. Akibtany Y mengalami sesuatu / kehilangan sesuatu.

\section{Menghapus}

$\mathrm{X}$ menyentuh Y dengan alat

$\mathrm{X}$ menggosok $\mathrm{Y}$

$\mathrm{X}$ mendapatkan suatu hasil dari

kegiatan tersebut 
X ingin menghilangkan sesuatu pada $\mathrm{Y}$

$\checkmark \quad$ Ia menghapus mulutnya dengan serbet kertas.

$\checkmark \quad$ Ia menghapus sketsanya yang salah

$\checkmark$ Budi tidak sengaja mengahapus namanya sendiri di lembar jawaban

\section{Menyeka}

$\mathrm{X}$ menyentuh $\mathrm{Y}$ dengan alat

$\mathrm{X}$ menggosok Y

$\mathrm{X}$ ingin membersihkan sesuatu yang ada pada $Y$

$\checkmark$ Sesudah menyeka meja, ia membenahi kursi-kursi.

$\checkmark$ Gadis itu menyeka keringat di wajahnya dengan saputangan.

$\checkmark \quad$ Ibu menyeka genangan air bekas tumpahan the ayah.

\section{Menggesek}

$\mathrm{X}$ menyentuh $\mathrm{Y}$ dengan alat

$\mathrm{X}$ menggosok $\mathrm{Y}$

$\mathrm{X}$ menghasilkan sesuatu dari kegiatan tersebut

$\checkmark \quad$ Ia pandai menggesek biola.

$\checkmark$ Kucing itu menggesek tubuhnya di kakiku

$\checkmark$ Jaman dulu manusia membuat api dengan cara menggesek dua batu Mengasah

$\mathrm{X}$ menyentuh $\mathrm{Y}$ dengan alat X menggosok Y
$\mathrm{X}$ ingin mendapatkan sesuatu dari kegitan tersebut $\mathrm{X}$ ingin menjadi lebih baik

Ayah mengasah parang untuk memotong dahan yang mengganggu.

$\checkmark \quad$ Ibu mengasah pisau yang sudah tidak tajam itu

$\checkmark$ Sebelum lebaran kurban, pak haji selalu mengasah goloknya.

\section{SIMPULAN}

Dari penelitian terhadap verba sentuh menggunakan teori MSA diatas, didapatlah kesimpulan yang dipaparkan oleh penulis;

1) Elemen makna asali yang membentuk turunan verba sentuh adalah [MERASAKAN], [MEMUKUL], [MENEKAN] dan [MENGGOSOK].

2) Adanya elemen lain yang bukan verba dalam pembentukan makna universal dari turunan verba sentuh seperti; 'seseorang' dan 'sesuatu'

3) Bagian yang digunakan untuk menyentuh, apa yang disentuh, adanya penggunaan alat dan munculnya efek pada objek merupakan hal-hal penting yang perlu diperhatikan untuk memunjulkan makna tiap-tiap verba turunan dari verba sentuh. 
Dari kesimpulan tersebut didapatlah pola makna dari verba sentuh yaitu setiap verba sentuh memiliki masing-masing unsur makna asali: (i) [MERASAKAN], bahwa ketika terjadi sentuhan adapula rasa yang diterima dari proses sentuhan. (ii) [MEMUKUL], verba sentuh adakalanya memiliki makna memukul secara pelan atau proses pukulan yang tidak memberikan efek sakit berlebih. (iii) [MENEKAN], adanya proses tekanan pada beberapa verba-verba sentuh. Sama seperti proses memukul, proses menekan pada verba sentuh terjadi pada sekala kecil, bukan sebuah tekanan dengan kekuatan yang penuh. (iv) [MENGGOSOK], dalam verba sentuh juga memunculkan makna menggosok didalamnya. Beberapa turunan verba sentuh menghasilkan makna menggosok namun masih sama seperti memukul dan menekan, makna memukul tersebut masih dalam skala yang rendah. Gesekan atau gosokan tersebut merupakan proses sentuhan dengan diikutin gerakan bolak-balik tanpa tekanan kuat dan menggunakan alat-alat tertentu.

\section{References}

Mulyadi. (2000). Struktur semantis verba penglihatan dalam bahasa Indonesia. Dalam Jurnal Linguistik Indonesia No.2 Tahun 18.

Mulyadi dan Rumasari K. Siregar. (2006). Aplikasi teori metabahasa makna alami dalam kajian makna. Dalam Jurnal Ilmiah Bahasa dan Sastra LOGAT Vol. II No. 2.

Mulyadi. (2009). Kategori dan peran semantis verba dalam bahasa indonesia. Dalam Jurnal Ilmiah Bahasa dan Sastra LOGAT Vol. V No. 1.

Miles, Matthew. B, A. M. Huberman dan J. Saldana. (2014). Qualitative data analysis [a methods sourcebook]. London: Sage Publications.

Saeed, John. I. (2003). Semantic 'second edition'. Blackwell: USA/UK

Subiyanto, Agus. (2011). Struktur semantis verba proses tipe kejadian bahasa jawa: kajian metabahasa semantik alami. Dalam Jurnal Kajian Linguistik dan Sastra Vol. 23

Wierzbicka, Anna. (1996). Semantics: Primes and Universals. Oxford: Oxford University Press. 